\title{
Stress management in dental students: a systematic review
}

This article was published in the following Dove Press journal:

Advances in Medical Education and Practice

28 May 2014

Number of times this article has been viewed

\author{
Abdullah M Alzahem' \\ Henk TVan der Molen ${ }^{2}$ \\ Arwa H Alaujan ${ }^{3}$ \\ Benjamin J De Boer ${ }^{4}$ \\ 'King Abdullah International Medical \\ Research Center, King Saud bin \\ Abdulaziz University for Health \\ Sciences, National Guard Health \\ Affairs, Riyadh, Saudi Arabia; \\ ${ }^{2}$ Institute of Psychology, Faculty of \\ Social Sciences, Erasmus University, \\ Rotterdam, the Netherlands; ${ }^{3}$ Dental \\ Services, Central Region, King \\ Abdulaziz Medical City, National \\ Guard Health Affairs, Riyadh, Saudi \\ Arabia; ${ }^{4}$ Clinical Psychology, Princess \\ Nora University, Riyadh, Saudi Arabia
}

Correspondence: Abdullah M Alzahem King Abdullah International Medical Research Center, King Saud bin Abdulaziz University for Health Sciences, National Guard Health Affairs, PO Box 22490, Mail Code I243, Riyadh I I426,

Saudi Arabia

Tel +966 I80 I I I I I

Fax +966 I80I 4010

Email zahema@ngha.med.sa

\begin{abstract}
This study compared the effectiveness of stress management programs in dental education by systematic review of the literature. The number of studies concerning stress management programs for dental students is limited compared with studies discussing sources of stress. Several types of programs for stress management have been reported, and differ in their duration, content, and outcomes. Two main strategies have been used to help stressed students, ie, decreasing the number of stressors and increasing the ability to cope with stress. The first strategy includes several components, such as reducing fear of failure and workload pressure due to examinations and requirements. The second strategy includes coping techniques, such as deep breathing exercises. Although positive effects have been reported for most of the programs, these have mainly been evaluated using subjective self-report measures. There is a need for more research to identify the most effective stress management program.
\end{abstract}

Keywords: students, dentistry, education, management, stress

\section{Introduction}

Dental students have a $100 \%$ prevalence of stress. ${ }^{1}$ Perception of stress is due to the tendency of dental students toward perfectionism based on their history of high achievement and excellence in previous schooling and the fact that excellence is the norm in dental school. ${ }^{2}$ The effect of year of study on stress levels has been found to be significant, with the third year of the 5-year curriculum considered the most stressful. ${ }^{3}$ Increasing stress may result in decreased student performance. ${ }^{4}$ Stress can be a significant threat and have a detrimental effect on the physical and/or mental health of students. ${ }^{5}$ Stress may also harm the trainee's professional effectiveness by decreasing attention, reducing concentration, impinging on decision-making skills, and reducing the ability to forge good clinician-patient relationships. ${ }^{6}$

In relation to the serious side effects of stress among students in the health professions, more than two decades ago Tisdelle et al reported the deficiency in stress management research and programs available for dental students. ${ }^{7}$ This observation has not been adequately addressed, despite numerous reports of the negative consequences of stress and recommendations to develop stress management programs for intervention and prevention. Although there is a large body of literature on stress management, its specific application to dental education has been largely unexplored. Compared with studies reporting the sources of stress, the number of studies discussing the prevention or management of stress in dental education is limited. However, a few researchers have studied the specific effects of stress management programs in dental education and some have provided empirical data. 
Thirty-eight sources of stress in five groupings have been identified, being stressors related to living accommodation, stressors related to personal factors, stressors related to educational environment, stressors related to academic work, and stressors related to clinical factors. ${ }^{5}$ Prevention and intervention procedures have been classified in six categories. ${ }^{5}$ Apart from these, one study done in India recommends that parents should be advised not to force their children to study something against their will, ${ }^{8}$ because they found that fear of facing parents after failure is a major source of stress, particularly in that part of the world.

Summarizing the literature, stressed students can help by either decreasing the number of stressors or by increasing their coping skills with regard to stress. ${ }^{9}$ Decreasing the number of stressors can be achieved in several ways, such as reducing fear of failure and workload pressure due to examinations and course requirements. ${ }^{9}$ In addition, the content of the dental curriculum could be reduced or its design changed. ${ }^{10}$ Clinical requirements can be reduced or deleted to decrease the number of stressors. ${ }^{9}$ Dodge et al found lower levels of stress among students in a clinical program based on patient needs than in students in a clinical program based on requirements. Further, students in programs without requirements have higher productivity and academic performance. ${ }^{11}$ Increasing the length of the curriculum in order to lower students' workload can help, and may also reduce their fear of failure. ${ }^{9}$ Stress caused by uncertainty during transition periods can be reduced by scheduling sessions for exchange of information between students and their classmates from one year ahead, which can be a good source of information for their juniors. ${ }^{9,12}$

Increasing students' ability to cope with stress is also important, and may help them in their future professional activities. Kay and Lowe suggest implementing stress management and wellness courses for students. ${ }^{13}$ Topics such as coping with stress, time management, and choosing realistic goals could be addressed. Moreover, overall wellness should be emphasized by discussing the importance of sleep, diet, exercise, and other stress relievers like yoga and meditation. Positive outcomes have been observed among dental and medical students in previous studies. ${ }^{14-17}$

The purpose of the present study was to systematically review the literature to identify stress management programs in dental education and to determine their effectiveness. We focused on programs that provided students with coping techniques, such as meditation, hypnosis, imagery, and muscle relaxation, education regarding the psychological and physiological effects of stress, affiliation with peers, opportunities for emotional expression (support groups), and intensified relationships with faculty. After review of the literature, we discuss the implications of integration of stress management into dental education, provide practical suggestions for decreasing and alleviating stress, and make suggestions for future research.

\section{Methods}

This systematic review was conducted after approval of the protocol by the institutional review board at the King Abdullah International Medical Research Center. Two reviewers (AMA, AHA) evaluated studies on stress management in dental students for inclusion. The aim of the evaluation was to assess the quality of the studies as objectively as possible. Assessment of quality included the study design, sampling (size and technique), the outcomes measured, and the reliability and accuracy of the data. The authors assessed the rigor of the selected studies according to the availability and quality of the study design, study sampling, response rate, measurement tool, and stress management program.

\section{Selection of studies}

The literature search primarily involved a search of PubMed (NLM), Library of Congress, LISTA (EBESCO), and Web of Science (TS). The key words used in our literature search were "dental", "dentistry", "education", "management", "stress", and "students". To narrow our search, the key words were combined by using AND as follows: "dental students stress management", dental AND students AND stress AND management, dental AND undergraduates AND stress AND management, dental AND students AND stress, dental AND undergraduates AND stress, dental AND education AND stress, dental AND education AND stress AND management, dentistry AND stress AND management. The reference lists of retrieved articles were also checked. Further, experts in stress management and behavioral psychology were contacted and asked about stress management programs for students. The citations identified in the electronic search were downloaded into EndNote X2, while those retrieved from other sources were entered manually (eg, hand searching, reference lists). Duplicates were deleted and a unique identification was assigned to each citation (author name and year of publication) on the review form.

A review form was designed (see Figure S1) to help determine which papers should be included in the study. A paper was included if it was published in the English language between January 1966 and November 2013, included undergraduate dental students, and investigated or discussed 
any stress management program. When the information provided by the title and abstracts was found to be relevant to the present research, or when this information was insufficient to decide on inclusion, the full text article was retrieved and evaluated. All remaining articles were read in their entirety and a final selection was made.

Data were extracted from the selected studies using a data extraction form (see Figure S2). The data extraction form included questions organized in three categories: general information (primary author, year of publication, country, journal); specific information (study design, study sample, stress management program); and analysis of outcomes (prevention, intervention). The review and data extraction forms were tested in a pilot study of a small number of papers. Based on the findings of the pilot, the forms were revised prior to use for identification of the articles included in the present study.

\section{Procedure}

The two reviewers (AMA, AHA) reviewed all the articles; the primary investigator was a consultant in dental services, program director, and a $\mathrm{PhD}$ student in a medical education program, and the other was a dental consultant interested in stress among dental professionals and students. The reviewers used the review and data extraction forms, and in case of a difference of opinion between the two reviewers, an expert was consulted to resolve the matter.

\section{Data analysis}

The results of the selected studies were combined and the findings reported most frequently were identified and summarized in tables. Aspects of stress management were categorized according to whether they were prevention or intervention programs. The results of all the papers included were reviewed to identify duplicate data, and a table was developed that included all aspects of stress management.

\section{Results}

Most of the literature addressing stress in dental students focused on the sources of stress and factors influencing the level of stress, such as gender and other demographic variables. Despite the call for stress management among dental students, only a small number of articles were found that discussed programs for managing these stressors in undergraduate dental students.

The initial electronic search by key words revealed 89 papers; after excluding duplicates and irrelevant papers by review of titles, this number was reduced to 22 (Figure 1).
The reviewers went through these 22 papers by reading the abstract, and after checking if the papers measured the effects of stress management programs in dental students, the number of papers was reduced further to 14. After reading the full text of these 14 papers, more papers were excluded according to the selection criteria, finally leaving seven papers for analysis (see Table S1).

Four of the studies selected were controlled trials, ${ }^{18-20}$ the fifth was a cross-sectional survey, the sixth was a case report, and the seventh was a systematic review addressing stress in dental students. ${ }^{1,5,21}$ The selected studies discussed different stress management programs, ranging from a short program to (one 60-minute session) a rather intensive program (60-90-minute sessions). Five of the selected studies reported intervention programs for stress management and the other two reported prevention programs. ${ }^{1,5,18-21}$ For six of the seven programs, the authors reported significant effects on stress reduction; however, no significant effect was found in one study. ${ }^{18}$

The stress management programs used varied in type, in that there were programs that trained students in specific relaxation strategies or techniques (ie, deep breathing, progressive muscle relaxation, Synchro-Energizer, yoga), ${ }^{1,18,19,20}$ other programs that introduced an interpersonal approach to dentistry (ie, faculty advising system, counseling

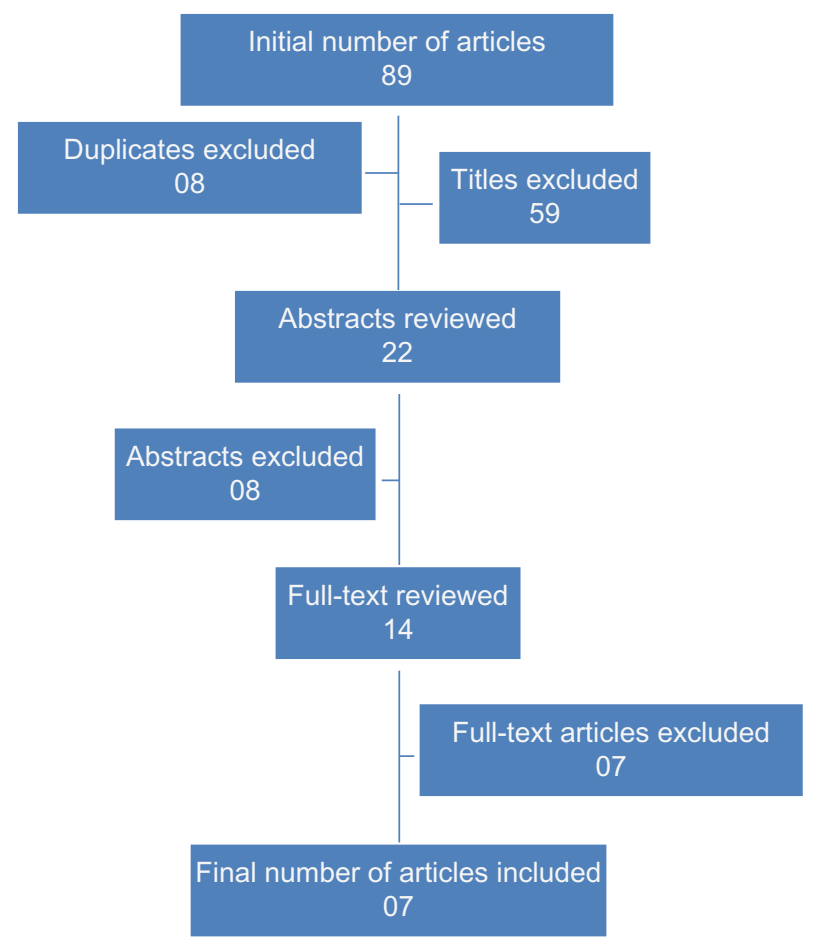

Figure I Articles screened for review. 
system, study and test-taking skills program, stress management workshop), ${ }^{21}$ and another program using multiple stress management seminars. ${ }^{7}$

Outcomes of the stress management programs were measured using multiple measurement tools including the Visual Analog Scale, ${ }^{18,19}$ Spielberger State-Trait Anxiety Inventory, ${ }^{18-20}$ COPE questionnaire, ${ }^{18}$ Dental Environment Stress questionnaire, ${ }^{1}$ Expectancy, ${ }^{7}$ Stress Knowledge Inventory, ${ }^{7}$ Profile of Mood States, ${ }^{20}$ Observer Rating Inventory, ${ }^{20}$ and Thurstone Temperament Schedule and Stanford Stress questionnaire. ${ }^{20}$

The variety of the stress management programs (Table 1) indicated that there are as yet no gold standards for the duration of such programs or the tools that can be used to assess their outcome. There are no stress management programs that deal with all sources of stress known from the literature.

\section{Discussion}

The aim of this study was to identify stress management programs in dental education, and to determine their effectiveness. To this end, we undertook a systematic review of the literature. Seven articles were selected and reviewed, but only four showed significant stress reduction using the suggested stress management programs. In almost all programs, the participants found them useful.

The number of studies discussing the content and effectiveness of stress management programs for dental students is limited, compared with studies discussing the sources of stress among dental students. The stress management programs reported in the literature for medical students were also limited, and included self-hypnosis, meditation, mindfulness-based stress reduction, changes in the "pass/ fail" grading system, feedback on various health habits, educational discussion, and changes in the length and type of curriculum provided. ${ }^{22}$ There were other studies discuss- ing stress management programs, but these do not focus on dental students specifically. Online stress management programs are effective if participants enjoy these, and have been shown to be more easily accessible and more cost-effective than traditional programs. ${ }^{23-25}$ Cognitive-behavioral stress management programs have been shown to be effective in reducing dysfunctional thought and decreasing stress. ${ }^{26,27}$ These general observations regarding stress management programs could be used to design programs specifically for dental students.

Different types of programs addressing stress management in dental students have been reported, but differ in their duration, content, and effect. These programs are either single or multiple sessions and contain relaxation techniques or information about stress. The shortest stress management program was a one-hour session, while the longest consisted of six 60-90-minute sessions. The stress management programs reported either helped to reduce the number of stressors or enhance stress coping skills, using relaxation techniques such as deep breathing and yoga. Stress management programs focused on stress prevention attempted to decrease the impact of stressors through stress awareness lectures.

The reported stress management programs did not follow one concept, and used either one measure or a combination of measures. For instance, some studies suggested improvement of the inter-professional relationship skills to reduce stress among dental students or used yoga; and the other studies used the Synchro-Energizer and Progressive Muscle Relaxation techniques, or combination of awareness and stress reduction exercise in multiple sessions. Most of these programs were liked by the students, helped them to manage their stress, and do not follow a gold standard. Hence, we recommend a program with easy application for students and dental schools, where students can achieve high outcomes with the least expenditure of time and effort.

Table I Summary of selected studies

\begin{tabular}{|c|c|c|c|c|c|}
\hline Reference & Year & Study sample & Study design & Outcomes measurement & Effectiveness \\
\hline Shankarapillai et al $^{19}$ & 2012 & 100 students & Controlled trial & VAS, STAI & Significant stress reduction \\
\hline Alzahem et $\mathrm{al}^{5}$ & 2011 & 49 articles & Systematic review & Data collection form & Not applicable \\
\hline Ahmad et al' & 2011 & 291 students & Cross-sectional & DES questionnaire & $90.3 \%$ stress reduction \\
\hline Piazza-Waggoner et al ${ }^{18}$ & 2003 & 26 students & Controlled trial & VAS, STAI, COPE questionnaire & No significant effect \\
\hline Howard et $\mathrm{al}^{20}$ & 1986 & 23 students & Controlled trial & $\begin{array}{l}\text { PMS, STAI, ORI, symptoms } \\
\text { questionnaire }\end{array}$ & $\begin{array}{l}\text { Stressed students benefited } \\
\text { the most }\end{array}$ \\
\hline Schwartz et $\mathrm{al}^{21}$ & 1984 & Dental students & Case report & Not available & Not available \\
\hline Tisdelle et $\mathrm{al}^{7}$ & 1984 & 17 students & Controlled trial & $\begin{array}{l}\text { Stress Knowledge Inventory, } \\
\text { STAI, Symptom Checklist, } \\
\text { physiological assessment }\end{array}$ & $\begin{array}{l}\text { Effective in reducing dental } \\
\text { students' physiological and } \\
\text { self-reported stress levels }\end{array}$ \\
\hline
\end{tabular}

Abbreviations: DES, Dental Environment Stress; VAS, visual analog scale; STAI, Spielberger State-Trait Anxiety Inventory; COPE, Coping Orientation for Problem Experiences; PMS, Profile of Mood States; ORI, Observer Rating Inventory. 
The huge impact of stress on dental students indicates a need for stress management programs in dental education. Such programs could be introduced in dental curricula; for example, by recruiting a clinical psychologist for dental students in dental schools. Based on our review, the following considerations should be incorporated into future research: rigorous study design, including randomized controlled trials; more detailed study of varying durations and frequencies of interventions (eg, single-session versus multiple-session programs); more objective outcome measures than self-reports; and the effects seen on long-term follow-up.

A limitation of this research might be the small number of studies selected for review. Therefore, future studies are needed to study the effectiveness of stress management programs for dental students.

This review highlights the importance of stress management programs, the promising start made by those already implemented and investigated, and the unexplored territory that must be charted if these interventions are to efficiently and effectively succeed in the twin goals of benefiting future dentists and their patients and establishing a sound scientific base for future research.

\section{Disclosure}

The authors report no conflicts of interest in this work.

\section{References}

1. Ahmad MS, Md Yusoff MM, Abdul Razak I. Stress and its relief among undergraduate dental students in Malaysia. Southeast Asian J Trop Med Public Health. 2012;42(4):996-1004.

2. Sanders AE, Lushington K. Sources of stress for Australian dental students. J Dent Educ. 1999;63(9):688-697.

3. Alzahem AM, Van der Molen HT, De Boer BJ. Effect of year of study on stress levels in male undergraduate dental students. Adv Med Educ Pract. 2013;4:217-222.

4. Westerman GH, Grandy TG, Lupo JV, Mitchell RE. Relationship of stress and performance among first-year dental students. J Dent Educ. 1986;50(5):264-267.

5. Alzahem AM, van der Molen HT, Alaujan AH, Schmidt HG, Zamakhshary MH. Stress amongst dental students: a systematic review. Eur J Dent Educ. 2011;15(1):8-18.

6. Shapiro SL, Shapiro DE, Schwartz GE. Stress management in medical education: a review of the literature. Acad Med. 2000;75(7):748-759.

7. Tisdelle DA, Hansen DJ, St Lawrence JS, Brown JC. Stress management training for dental students. J Dent Educ. 1984;48(4):196-202.

8. Acharya S. Factors affecting stress among Indian dental students. J Dent Educ. 2003:67(10);1140-1148.
9. Dahan H, Bedos C. A typology of dental students according to their experience of stress: a qualitative study. J Dent Educ. 2010;74(2):95-103.

10. Brand AA. Student attitude to dentistry in South African Dental schools. J Dent Assoc S Afr. 1997;52:713-720.

11. Dodge WW, Dale RA, Hendricson WD. A preliminary study of the effect of eliminating requirements on clinical performance. $J$ Dent Educ. 1993;57(9):667-672.

12. Westerman GH, Grandy TG, Ocanto RA, Erskine CG. Perceived sources of stress in the dental school environment. $J$ Dent Educ. 1993;57(3): 225-231.

13. Kay EJ, Lowe JC. A survey of stress levels, self-perceived health and health-related behaviours of UK dental practitioners in 2005. Br Dent J. 2008;204(11):E19.

14. Pau AK, Croucher, R. Emotional intelligence and perceived stress in dental undergraduates. J Dent Educ. 2003;67(9):1023-1028.

15. Newbury-Birch D, Lowry RJ, Kamali F. The changing patterns of drinking, illicit drug use, stress, anxiety and depression in dental students in a UK dental school: a longitudinal study. Br Dent J. 2002;192(11): 646-649.

16. Freeman R. Dental students in Northern Ireland in 1992 and 1995: changing trends in psychological stress. Stress Med. 2000;16:233-238.

17. Morse Z, Dravo U. Stress levels of dental students at the Fiji School of Medicine. Eur J Dent Educ. 2007;11(2):99-103.

18. Piazza-Waggoner CA, Cohen LL, Kohli K, Taylor BK. Stress management for dental students performing their first pediatric restorative procedure. J Dent Educ. 2003;67(5):542-548.

19. Shankarapillai R, Nair MA, George R. The effect of yoga in stress reduction for dental students performing their first periodontal surgery: a randomized controlled study. Int J Yoga. 2012;5(1):48-51.

20. Howard CE, Graham LE 2nd, Wycoff SJ. A comparison of methods for reducing stress among dental students. J Dent Educ. 1986;50(9): $542-544$.

21. Schwartz RM, Eigenbrode CR, Cantor O. A comprehensive stressreduction program for dental students. J Dent Educ. 1984;48(4): 203-207.

22. Shiralkar MT, Harris TB, Eddins-Folensbee FF, Coverdale JH. A systematic review of stress-management programs for medical students. Acad Psychiatry. 2013;37(3):158-164.

23. Morledge TJ, Allexandre D, Fox E, et al. Feasibility of an online mindfulness program for stress management - a randomized, controlled trial. Ann Behav Med. 2013;46(2):137-148.

24. Williams A, Hagerty BM, Brasington SJ, Clem JB, Williams DA. Stress gym: feasibility of deploying a web-enhanced behavioral self-management program for stress in a military setting. Mil Med. 2010;175(7):487-493.

25. Kawai K, Yamazaki Y, Nakayama K. Process evaluation of a web-based stress management program to promote psychological well-being in a sample of white-collar workers in Japan. Ind Health. 2010;48(3): 265-274.

26. Moeini B, Hazavehei SM, Hosseini Z, Aghamolaei T, Moghimbeigi A. The impact of cognitive-behavioral stress management training program on job stress in hospital nurses: applying PRECEDE model. J Res Health Sci. 2011;11(2):114-120.

27. Leung SS, Chiang VC, Chui YY, Mak YW, Wong DF. A brief cognitivebehavioral stress management program for secondary school teachers. J Occup Health. 2010;53(1):23-35. 


\section{Supplementary material}

Study ID:

\section{Study review}

I. Screening questions

a. Does the study include data on stress management? Yes No

b. Has the study been done on undergraduate dental students? Yes No

c. Has the study has been written in English? Yes No

Note: If any answer is "no", that study will be excluded.

II. Assessment

a. Excluded following initial screening (Abstract). Yes No

b. Excluded following full text screening. Yes No

If excluded why

Figure SI Study review form.

I. General information

a. Primary author.

b. Year of publication

c. Journal

d. Country

II. Specific information

a. Study design

b. Study sample

c. Stress management program

III. Outcomes

a. Prevention

b. Intervention

C. Duration

d. Outcomes measurement

e. Effectiveness

Reviewer signature:

Date:

Figure S2 Data extraction form. 
Table SI Reference checklist

Table SI Reference checklist

I. Shankarapillai R, Nair MA, George R. The effect of yoga in stress reduction for dental students performing their first periodontal surgery: a randomized controlled study. Int J Yoga. 20I2;5(I):48-5I.

2. Divaris K, Polychronopoulou A, Taoufik K, Katsaros C, Eliades T. Stress and burnout in postgraduate dental education. Eur J Dent Educ. 2012; I6(I):35-42.

3. Ahmad MS, Md Yusoff MM, Abdul Razak I. Stress and its relief among undergraduate dental students in Malaysia. Southeast Asian J Trop Med Public Health. 2012;42(4):996-1004.

4. Tangade PS, Mathur A, Gupta R, Chaudhary S. Assessment of stress level among dental school students: an Indian outlook. Dent Res J (Isfahan). 2011;8(2):95-101.

5. Pani SC, Al Askar AM, Al Mohrij SI, Al Ohali TA. Evaluation of stress in finalyear Saudi dental students using salivary cortisol as a biomarker.J Dent Educ. 20II;75(3):377-384.

6. Jurkat H, Hofer S, Richter L, Cramer M, Vetter A. [Quality of life, stress management and health promotion in medical and dental students. A comparative study]. Dtsch Med Wochenschr. 201 I;136(23):1245-1250. German.

7. Huth KC, Chen HY, Mehl A, Hickel R, Manhart J. Clinical study of indirect composite resin inlays in posterior stress-bearing cavities placed by dental students: results after 4 years. J Dent. 20I I;39(7):478-488.

8. Alzahem AM, van der Molen HT, Alaujan AH, Schmidt HG, Zamakhshary MH. Stress amongst dental students: a systematic review. Eur J Dent Educ. 201 I;I5(I):8-18.

9. Abu-Ghazaleh SB, Rajab LD, Sonbol HN. Psychological stress among dental students at the University of Jordan. J Dent Educ. 20 I ; 75(8): I I07-I I I4.

10. Silverstein ST, Kritz-Silverstein D. A longitudinal study of stress in first-year dental students. J Dent Educ. 2010;74(8):836-848.

II. Polychronopoulou A, Divaris K. A longitudinal study of Greek dental students' perceived sources of stress. J Dent Educ. 2010;74(5):524-530.

12. Manhart J, Chen HY, Mehl A, Hickel R. Clinical study of indirect composite resin inlays in posterior stress-bearing preparations placed by dental students: results after 6 months and I, 2, and 3 years. Quintessence Int. 20I0;4I (5):399-4I0.

13. Hinshaw KJ, Richter LT, Kramer GA. Stress, burnout, and renewal activities of dental hygiene education administrators in six US Midwestern States. J Dent Educ. 2010;74(3):235-250.

14. Dahan H, Bedos C. A typology of dental students according to their experience of stress: a qualitative study. J Dent Educ. 2010;74(2):95-103.

15. Polychronopoulou A, Divaris K. Dental students' perceived sources of stress: a multi-country study. J Dent Educ. 2009;73(5):63I-639.

16. Peker I, Alkurt MT, Usta MG, Turkbay T. The evaluation of perceived sources of stress and stress levels among Turkish dental students. Int Dent J. 2009;59(2): 103-III.

17. Laurence B, Williams C, Eiland D. Depressive symptoms, stress, and social support among dental students at a historically black college and university. J Am Coll Health. 2009;58(I):56-63.

18. Kumar S, Dagli RJ, Mathur A, Jain M, Prabu D, Kulkarni S. Perceived sources of stress amongst Indian dental students. Eur J Dent Educ. 2009; I3(I):39-45.

19. Schmitter M, Liedl M, Beck J, Rammelsberg P. Chronic stress in medical and dental education. Med Teach. 2008;30(I):97-99.

20. Muirhead V, Locker D. Canadian dental students' perceptions of stress and social support. Eur J Dent Educ. 2008; 12(3): 144-148.

21. Gorter R, Freeman R, Hammen S, Murtomaa H, Blinkhorn A, Humphris G. Psychological stress and health in undergraduate dental students: fifth year outcomes compared with first year baseline results from five European dental schools. Eur J Dent Educ. 2008; 12(2):61-68.

Title Abstract Full-text Exclusion reason

$x$

$x$

$X$

$$
X
$$

$x$

$X$

$X$

$x$

$\mathrm{X}$

$x$

$X$

$x$

$x$

$\mathrm{X}$

$x$
Not on undergraduate students

No management program

No management program

No management program

Not related to students stress management

\author{
No management \\ program \\ No management \\ program \\ No management \\ program \\ Not related to students' \\ stress management
}

Not related to dental students

$x$

No management. Former students

No management program

No management program

No management program

No management program No management program No management program No management program 
Table SI (Continued)

\begin{tabular}{|c|c|c|c|c|c|}
\hline & & Title & Abstract & Full-text & Exclusion reason \\
\hline 22. & $\begin{array}{l}\text { Muirhead V, Locker D. Canadian dental students' perceptions of stress. } \\
\text { J Can Dent Assoc. 2007;73(4):323. }\end{array}$ & $x$ & & & $\begin{array}{l}\text { No management } \\
\text { program }\end{array}$ \\
\hline 23. & $\begin{array}{l}\text { Morse Z, Dravo U. Stress levels of dental students at the Fiji School of } \\
\text { Medicine. Eur J Dent Educ. 2007; I I (2):99-103. }\end{array}$ & $x$ & & & $\begin{array}{l}\text { No management } \\
\text { program }\end{array}$ \\
\hline 24. & $\begin{array}{l}\text { Sofola OO, Jeboda SO. Perceived sources of stress in Nigerian dental } \\
\text { students. Eur J Dent Educ. 2006;10(I):20-23. }\end{array}$ & $x$ & & & $\begin{array}{l}\text { No management } \\
\text { program }\end{array}$ \\
\hline 25. & $\begin{array}{l}\text { Sugiura G, Shinada K, Kawaguchi Y. Psychological well-being and perceptions } \\
\text { of stress amongst Japanese dental students. Eur J Dent Educ. 2005;9(I):17-25. }\end{array}$ & $x$ & & & $\begin{array}{l}\text { No management } \\
\text { program }\end{array}$ \\
\hline 26. & $\begin{array}{l}\text { Rosli TI, Abdul Rahman R, Abdul Rahman SR, Ramli R. A survey of perceived } \\
\text { stress among undergraduate dental students in Universiti Kebangsaan } \\
\text { Malaysia. Singapore Dent J. } 2005 ; 27(\mathrm{I}): 17-22 \text {. }\end{array}$ & $x$ & & & $\begin{array}{l}\text { No management } \\
\text { program }\end{array}$ \\
\hline 27. & $\begin{array}{l}\text { Rasmussen JK, Frederiksen JA, Hallonsten AL, Poulsen S. Danish dentists' } \\
\text { knowledge, attitudes and management of procedural dental pain in children: } \\
\text { association with demographic characteristics, structural factors, perceived } \\
\text { stress during the administration of local analgesia and their tolerance towards } \\
\text { pain. Int J Paediatr Dent. 2005;15(3):159-168. }\end{array}$ & $x$ & & & $\begin{array}{l}\text { Not related to dental } \\
\text { students' stress } \\
\text { management }\end{array}$ \\
\hline 28. & $\begin{array}{l}\text { Polychronopoulou A, Divaris K. Perceived sources of stress among Greek } \\
\text { dental students. J Dent Educ. 2005;69(6):687-692. }\end{array}$ & $x$ & & & $\begin{array}{l}\text { No management } \\
\text { program }\end{array}$ \\
\hline 29. & $\begin{array}{l}\text { Pohlmann K, Jonas I, Ruf S, Harzer W. Stress, burnout and health in the } \\
\text { clinical period of dental education. Eur J Dent Educ. } 2005 ; 9(2): 78-84 \text {. }\end{array}$ & & $x$ & & $\begin{array}{l}\text { No management } \\
\text { program }\end{array}$ \\
\hline 30. & $\begin{array}{l}\text { Friedlander AH, Friedlander IK, Marder SR. Posttraumatic stress disorder: } \\
\text { psychopathology, medical management, and dental implications. Oral Surg Oral } \\
\text { Med Oral Pathol Oral Radiol Endod. 2004;97(I):5-II. }\end{array}$ & $x$ & & & \\
\hline 31. & $\begin{array}{l}\text { Cardoso CL, Loureiro SR, Nelson-Filho P. Pediatric dental treatment: } \\
\text { manifestations of stress in patients, mothers and dental school students. Braz } \\
\text { Oral Res. } 2004 ; 18(2): 150-155 .\end{array}$ & $x$ & & & \\
\hline 32. & $\begin{array}{l}\text { Piazza-Waggoner CA, Cohen LL, Kohli K, Taylor BK. Stress management for } \\
\text { dental students performing their first pediatric restorative procedure. J Dent } \\
\text { Educ. } 2003 ; 67(5): 542-548 .\end{array}$ & & & & \\
\hline 33. & $\begin{array}{l}\text { Acharya S. Factors affecting stress among Indian dental students. J Dent Educ. } \\
\text { 2003;67(I0): | | } 40-1 \mid 48 .\end{array}$ & $x$ & & & \\
\hline 34. & $\begin{array}{l}\text { Newbury-Birch D, Lowry RJ, Kamali F. The changing patterns of drinking, } \\
\text { illicit drug use, stress, anxiety and depression in dental students in a UK } \\
\text { dental school: a longitudinal study. Br Dent J. 2002;192(II):646-649. }\end{array}$ & & $x$ & & \\
\hline 35. & $\begin{array}{l}\text { Naidu RS, Adams JS, Simeon D, Persad S. Sources of stress and psychological } \\
\text { disturbance among dental students in the West Indies. J Dent Educ. } \\
\text { 2002;66(9): } 1021-1030 .\end{array}$ & $x$ & & & \\
\hline 36. & $\begin{array}{l}\text { Humphris G, Blinkhorn A, Freeman R, et al. Psychological stress in } \\
\text { undergraduate dental students: baseline results from seven European dental } \\
\text { schools. Eur J Dent Educ. 2002;6(I):22-29. }\end{array}$ & & $x$ & & \\
\hline 37. & $\begin{array}{l}\text { Rajab LD. Perceived sources of stress among dental students at the University } \\
\text { of Jordan. J Dent Educ. } 2001 ; 65(3): 232-241 \text {. }\end{array}$ & $x$ & & & \\
\hline 38. & $\begin{array}{l}\text { Sanders AE, Lushington K. Sources of stress for Australian dental students. } \\
\text { J Dent Educ. 1999;63(9):688-697. }\end{array}$ & $x$ & & & \\
\hline 39. & $\begin{array}{l}\text { Heath JR, MacFarlane TV, Umar MS. Perceived sources of stress in dental } \\
\text { students. Dent Update. I999;26(3):94-98, } 100 .\end{array}$ & $x$ & & & \\
\hline 40. & $\begin{array}{l}\text { Peretz B, Rosenblum A, Zadik D. Stress levels and related variables among } \\
\text { dental students in Jerusalem, Israel. Eur J Dent Educ. 1997; I (4):162-166. }\end{array}$ & $x$ & & & \\
\hline 41. & $\begin{array}{l}\text { Newton JT, Baghaienaini F, Goodwin SR, Invest J, Lubbock M, Marouf } \\
\text { Saghakhaneh N. Stress in dental school: a survey of students. Dent Update. } \\
\text { 1994;2 I (4):I62-164. }\end{array}$ & $x$ & & & \\
\hline 42. & $\begin{array}{l}\text { Hendricks SJ, Joshi A, Crombie K, Moola MH. Perceived sources of stress } \\
\text { among black dental students in South Africa. J Dent Educ. 1994;58(6):406-410. }\end{array}$ & $x$ & & & \\
\hline 43. & $\begin{array}{l}\text { Reyes RE. Stress management in pediatric dentistry. N Y State Dent J. } \\
\text { 1993;59(2):22-23. }\end{array}$ & & $x$ & & \\
\hline 44. & $\begin{array}{l}\text { Lopez Rendon JM, Ochoa Garcia JD, Velez Betancur JC. [Diagnosis and } \\
\text { proposed solutions to causes of stress in students in the clinic of the CES } \\
\text { Health Science Institute Dental School]. CES Odontol. 1990;3(2):83-94. Spanish. }\end{array}$ & & NA & $x$ & \\
\hline
\end{tabular}

(Continued) 
Table SI (Continued)

\begin{tabular}{|c|c|c|c|c|c|}
\hline & & Title & Abstract & Full-text & Exclusion reason \\
\hline 45. & $\begin{array}{l}\text { Sgan-Cohen HD. Stress among Israeli dental students: a two-year longitudinal } \\
\text { study. Int J Psychosom. 1989;36(I-4):69-7I. }\end{array}$ & $x$ & & & \\
\hline 46. & $\begin{array}{l}\text { Rubenstein LK, May TM, Sonn MB, Batts VA. Physical health and stress in } \\
\text { entering dental students. J Dent Educ. 1989;53(9):545-547. }\end{array}$ & & & $X$ & $\begin{array}{l}\text { No management } \\
\text { program }\end{array}$ \\
\hline 47. & $\begin{array}{l}\text { Grandy TG, Westerman GH, Combs CE, Turner CH. Perceptions of stress } \\
\text { among third-year dental students. J Dent Educ. 1989;53(I2):718-72I. }\end{array}$ & $X$ & & & \\
\hline 48. & $\begin{array}{l}\text { Sgan-Cohen HD, Lowental U. Sources of stress among Israeli dental students. } \\
\text { J Am Coll Health. 1988;36(6):317-32I. }\end{array}$ & $X$ & & & \\
\hline 49. & $\begin{array}{l}\text { Grandy TG, Westerman GH, Lupo JV, Combs CG. Stress symptoms among } \\
\text { third-year dental students. J Dent Educ. 1988;52(5):245-249. }\end{array}$ & $X$ & & & \\
\hline 50. & $\begin{array}{l}\text { Friedlander AH, Mills MJ, Wittlin BJ. Dental management considerations for } \\
\text { the patient with post-traumatic stress disorder. Oral Surg Oral Med Oral Pathol. } \\
\text { 1987;63(6):669-673. }\end{array}$ & $X$ & & & \\
\hline 51. & $\begin{array}{l}\text { Cecchini JJ, Friedman N. First-year dental students: relationship between } \\
\text { stress and performance. Int J Psychosom. 1987;34(3):17-19. }\end{array}$ & $X$ & & & \\
\hline 52. & $\begin{array}{l}\text { Westerman GH, Grandy TG, Lupo JV, Mitchell RE. Relationship of stress and } \\
\text { performance among first-year dental students. J Dent Educ. 1986;50(5):264- } \\
267 .\end{array}$ & $X$ & & & \\
\hline 53. & $\begin{array}{l}\text { Register J. Dental students today. Feeling pressure/stress. Fla Dent J. } \\
\text { 1986;57(2):6-7,58-59. }\end{array}$ & & & $x$ & $\begin{array}{l}\text { No management } \\
\text { program }\end{array}$ \\
\hline 54. & $\begin{array}{l}\text { Howard CE, Graham LE 2nd, Wycoff SJ. A comparison of methods for } \\
\text { reducing stress among dental students. J Dent Educ. 1986;50(9):542-544. }\end{array}$ & & & & \\
\hline 55. & $\begin{array}{l}\text { [No authors listed]. Management of stress in the dental practitioner. Dent Clin } \\
\text { North Am. 1986;30(Suppl 4):SI-SI46. }\end{array}$ & $X$ & & & Not on students \\
\hline 56. & $\begin{array}{l}\text { Musser LA, Lloyd C. The relationship of marital status and living arrangement } \\
\text { to stress among dental students. J Dent Educ. 1985;49(8):573-578. }\end{array}$ & $X$ & & & \\
\hline 57. & $\begin{array}{l}\text { Lloyd C, Musser LA. Stress in dental students. J Am Coll Dent. } \\
\text { 1985;52(2):1 I-19. }\end{array}$ & & & $X$ & $\begin{array}{l}\text { No management } \\
\text { program }\end{array}$ \\
\hline 58. & $\begin{array}{l}\text { Tisdelle DA, Hansen DJ, St Lawrence JS, Brown JC. Stress management } \\
\text { training for dental students. J Dent Educ. 1984;48(4): 196-202. }\end{array}$ & & & & \\
\hline 59. & $\begin{array}{l}\text { Sebor RJ. Stress: inherent to dentists or taught to dental students? Dent Stud. } \\
\text { 1984;63(I):14-20. }\end{array}$ & & & $x$ & $\begin{array}{l}\text { No management } \\
\text { program }\end{array}$ \\
\hline 60. & $\begin{array}{l}\text { Schwartz RM, Eigenbrode CR, Cantor O. A comprehensive stress-reduction } \\
\text { program for dental students. J Dent Educ. 1984;48(4):203-207. }\end{array}$ & & & & \\
\hline 61. & $\begin{array}{l}\text { Ravins H. Dental orthopedics - stress management. Basal Facts. } \\
\text { I984;6(I):30-3I. }\end{array}$ & & & $X$ & Not study (note) \\
\hline 62. & $\begin{array}{l}\text { Grandy TG, Westerman GH, Mitchell RE, Lupo JV. Stress among first-year } \\
\text { dental students. J Dent Educ. 1984;48(I0):560-562. }\end{array}$ & & & $X$ & $\begin{array}{l}\text { No management } \\
\text { program }\end{array}$ \\
\hline 63. & $\begin{array}{l}\text { Cohen H, Hurwitz M, Lanesman B, Myburg N, Prinsloo B. The perception } \\
\text { and response to stress by dental students of the University of Witwatersrand. } \\
\text { Diastema. 1982;10:16-21. }\end{array}$ & $X$ & & & \\
\hline 64. & $\begin{array}{l}\text { Garbee WH Jr, Zucker SB, Selby GR. Perceived sources of stress among } \\
\text { dental students. J Am Dent Assoc. 1980; 100(6):853-857. }\end{array}$ & $X$ & & & \\
\hline 65. & $\begin{array}{l}\text { Goldstein MB. Sources of stress and interpersonal support among first-year } \\
\text { dental students. J Dent Educ. 1979;43(I2):625-629. }\end{array}$ & & & $X$ & $\begin{array}{l}\text { No management } \\
\text { program }\end{array}$ \\
\hline 66. & $\begin{array}{l}\text { Jackson E, Mealiea WL Jr. Stress management and personal satisfaction in } \\
\text { dental practice. Dent Clin North Am. 1977;2 I(3):559-576. }\end{array}$ & & $x$ & & \\
\hline 67. & $\begin{array}{l}\text { Lobene RR, Fredericks M, Mundy P. The relationship between social class } \\
\text { stress - anxiety responses, achievement, and professional attitudes of dental } \\
\text { hygiene students. J Am Dent Hyg Assoc. 1972;46(2): I I3-1 I } 7 \text {. }\end{array}$ & $x$ & & & \\
\hline 68. & $\begin{array}{l}\text { Lobene RR, Fredricks MA, Mundy P. The relationship between social class, } \\
\text { stress anxiety responses, academic achievement and professional attitudes of } \\
\text { students of dental assisting. Dent Assist. 1971;40(8):I I-15. }\end{array}$ & $X$ & & & \\
\hline 69. & $\begin{array}{l}\text { Fredericks MA, Mundy P. Relations between social class, stress-anxiety } \\
\text { responses, academic achievement, and professional attitudes of dental } \\
\text { students. J Dent Educ. 1969;33(3):377-384. }\end{array}$ & $X$ & & & \\
\hline 70. & $\begin{array}{l}\text { Fredericks MA, Mundy P. Dental students: relationship between social class, } \\
\text { stress, achievement, and attitudes. J Am Coll Dent. 1967;34(4):218-228. }\end{array}$ & $X$ & & & \\
\hline
\end{tabular}


Advances in Medical Education and Practice

Dovepress

\section{Publish your work in this journal}

Advances in Medical Education and Practice is an international, peerreviewed, open access journal that aims to present and publish research on Medical Education covering medical, dental, nursing and allied health care professional education. The journal covers undergraduate education, postgraduate training and continuing medical education

including emerging trends and innovative models linking education, research, and health care services. The manuscript management system is completely online and includes a very quick and fair peer-review system. Visit http://www.dovepress.com/testimonials.php to read real quotes from published authors.

Submit your manuscript here: http://www.dovepress.com/advances-in-medical-education-and-practice-journal 